\title{
A new Pasteurella species (?) from a wound infection
}

\author{
J. BRODIE AND A. HENDERSON \\ From the Laboratory, City Hospital, Aberdeen
}

SYNOPSIS A case of appendicitis is described in which the wound was infected with an organism of the genus Pasteurella. The morphological and biochemical properties of the strain are recorded, and comparison is made with other species of the same genus. It is concluded that this strain may be a new species.

\section{HISTORY}

An 80-year-old woman, living in a fairly remote country village in Aberdeenshire, was admitted to hospital complaining of vague, generalized abdominal discomfort and nausea. Laparotomy revealed a ruptured gangrenous appendix which was removed. The patient made an apparently uneventful recovery, However, three weeks later, large quantities of foul pus were discharged from the wound without any particular upset to the patient. After two days the discharge ceased.

\section{HISTOLOGY}

The mucosa of the appendix had sloughed leaving a circumferential abscess. The entire thickness of the wall showed polymorphonuclear infiltration and many small Gram-negative bacilli were noted.

\section{BACTERIOLOGY}

Aerobic and anerobic cultures of the pus both yielded a profuse growth of minute Gram-negative cocco-bacilli only. No bipolar staining was demonstrated. The organism grew readily on nutrient agar and MacConkey's bile salt agar and showed beta haemolysis on horse blood agar. Growth was good at both room temperature and at $37^{\circ} \mathrm{C}$. The organism was motile at $22^{\circ} \mathrm{C}$. but not at $37^{\circ} \mathrm{C}$. The biochemical properties are shown in Table I. The patient's serum, taken approximately three weeks after the onset of the appendicitis, agglutinated a saline suspension of the organism to a titre of 1 in 32 only. An overnight culture inoculated intraperitoneally in $0.2 \mathrm{ml}$. volumes into three mice resulted in the death of all three mice in $\mathbf{1 8}$ hours. The organism was recovered from the heart blood and peritoneum of the animals.

Although motile at $22^{\circ} \mathrm{C}$, the present isolate differs from $P$. pseudotuberculosis in that it produces indole, is methyl red-negative, is beta haemolytic, and fails to ferment rhamnose and mannitol.

The haemolytic and avid urea-splitting properties of the organism seemed to suggest that it might be Pasteurella haemolytica var. ureae. Infections with this organism were first reported by Henriksen and Jyssum (1960) and, in Britain, by Jones and O'Connor (1962). Cultures were obtained from these investigators and compared with the organism isolated from this patient. Cultures of Pasteurella pneumotropica, also from Dr. Henriksen, were included because of its urea-splitting characteristic. The comparative results are set forth in Table I.

\section{RESULTS}

The properties of the strains of Pasteurella haemolytica var. ureae were reasonably similar to each other in our hands. Our strain differed from Pasteurella haemolytica var. ureae in that it grew readily on nutrient agar, MacConkey's lactose bile salt agar, and in glucose phosphate medium; was strongly beta haemolytic; produced indole from peptone water; fermented glycerol, arabinose, and xylose; failed to ferment mannitol; was motile at $22^{\circ} \mathrm{C}$. but not motile at $37^{\circ} \mathrm{C}$.; and was pathogenic for mice.

The present strain differed from Pasteurella pneumotropica in the production of hydrogen sulphide; in not fermenting mannose, trehalose, and salicin; in growing on MacConkey's lactose bile salt agar and on nutrient agar; and in being motile at $22^{\circ} \mathrm{C}$. but not motile at $37^{\circ} \mathrm{C}$.

\section{DISCUSSION}

After Pasteurella pestis, the next most frequent Pasteurella sp. giving rise to human infections appears to be $P$. multocida (syn. septica). This 
TABLE I

COMPARISON OF PROPERTIES OF PRESENT STRAIN, P. HAEMOLYTICA VAR UREAE AND P. PSEUDOTROPICA

\begin{tabular}{|c|c|c|c|c|c|c|}
\hline \multirow[t]{2}{*}{ Characteristic } & \multirow[t]{2}{*}{ Present Strain } & \multirow{2}{*}{$\begin{array}{l}\text { P. haemolytica } \\
\text { var. ureae (Jones) }\end{array}$} & \multicolumn{2}{|c|}{ P. haemolytica var. ureae (Henriksen) } & \multicolumn{2}{|l|}{ P. pseudotropica } \\
\hline & & & Serotype 1 & Serotype 2 & Strain 953 & Strain 4225 \\
\hline \multicolumn{7}{|l|}{ Blood agar } \\
\hline $\begin{array}{l}\text { Colony }(48 \mathrm{hr} .) \\
\text { Haemolysis }\end{array}$ & $\begin{array}{l}2 \mathrm{~mm} . \text {, transparent, } \\
\text { yellowish } \\
\text { Beta }\end{array}$ & $\begin{array}{l}<1 / \mathrm{mm} . \\
\text { transparent } \\
\text { Alpha }\end{array}$ & $\begin{array}{l}<1 / \mathrm{mm} . \\
\text { transparent } \\
\text { Alpha }\end{array}$ & $\begin{array}{l}<1 / \mathrm{mm} . \\
\text { transparent } \\
\text { Alpha }\end{array}$ & $\begin{array}{l}2 \mathrm{~mm} . \text {, ground- } \\
\text { glass } \\
\text { - }\end{array}$ & $\begin{array}{l}2 \mathrm{~mm} ., \text { ground- } \\
\text { glass }\end{array}$ \\
\hline
\end{tabular}

Motility

$22^{\circ} \mathrm{C}$

$37^{\circ} \mathrm{C}$.

Aerobic

Anaerobic

Gelatin liquefaction

Oxidase

Catalase

Voges-Proskauer test

Methyl red test

Indole

Ammonia production

Citrate utilization

Nitrite production

Urea

Carbohydrates

Pentoses

Arabinose

Xylose

Rhamnose

Hexoses

Glucose

Fructose

Galactose

Mannose

Disaccharides

Sucrose

Maltose

Lactose

Trehalose

Trisaccharide

Raffinose

Polysaccharides

Inulin

Dextrin

Alcohols

Adonitol

Mannitol

Dulcitol

Sorbitol

Glycerol

Glycosides

Salicin

Aesculin

Inositol

$+=$ reaction obtained

$\pm=$ acid produced without gas.

organism has been reported in puerperal pyrexia by Brugnatelli (1913); in empyemata by Debré (1919), Hundeshagen (1919), Ortscheit (1921), Teissier Gastinel, Reilly, and Rivalier (1922), and Brodie and Henderson (1960); in sputum by Foerster (1938), Mulder (1938), Bezjak and Mimica (1952), Cawson and Talbot (1955), Brodie and Henderson (1963); from the paranasal sinuses and pharynx by Debré
(1919), Bartley and Hunter (1947), and Bartley (1960); in appendicitis and intestinal infections by von Boèr (1917), Ludlam (1944), Bezjak and Mimica (1952), and Coghlan (1958); in joint infections by Robinson (1944) and Pizey (1953); and in wounds following animal bites by Regamey (1938), Boisvert and Fousek (1941), Allin (1942), Allott, Cruickshank, Cyrlas-Williams, Glass, Meyer, Straker, and Tee 
(1944), Cooper and Moore (1945), Brundson and Mallett (1953), Mautner and McIntyre (1956), Emson (1957), McGeachie (1958), Williams (1960), Lee and Buhr (1960), and Brodie and Henderson (1963).

Other Pasteurella spp. giving rise to human infection include $P$. pseudotuberculosis. In Germany, Knapp (1954) and Knapp and Masshoff (1954) first reported the recovery of $\boldsymbol{P}$. pseudotuberculosis from mesenteric lymph nodes in two children operated on for appendicitis. Mair, Mair, Stirk, and Corson (1960), in England, examined faeces, blood, appendix, and lymph glands in 12 patients with mesenteric adenitis. From two of the cases $P$. pseudotuberculosis was isolated and in a third case, although the organism was not recovered, the patient's serum agglutinated the organism to a titre of $1: 300$. In a further communication, Randall and Mair (1962) described pseudotuberculous mesenteric adenitis in a boy aged 14. Although $P$. pseudotuberculosis was not recovered from the lesions, the boy's serum agglutinated this organism to a titre of 1:500 and it was further found that his three sibs had, for this organism, titres of $1: 500,1: 200$, and $1: 100$, and the family Corgi dog a titre of $1: 100$. Further cases of familial infection have been described by Lataix, Mollaret, Coulet, and Perny (1959) and Mollaret (1960). In 1961, Daniëls, in Holland, investigated five patients known to be suffering from Masshoff's enteritis and recovered the organism from the faeces of one case.

Three instances of the isolation of $P$. haemolytica var. ureae from the human nasal passages have been reported by Henriksen and Jyssum (1960). These same authors (1961) recorded a further seven instances of the presence of this organism in the human upper respiratory tract and later in the same year Omland and Henriksen (1961) added two more isolations from the same source. These communications were followed by a serological investigation of these isolates by Henriksen (1961) who reported that $P$. haemolytica var. ureae could be divided into two serological types of which type 1 had a type-specific capsular antigen. Jones (1962) and Jones and O'Connor (1962) in the Manchester area isolated some 30 strains of $P$. haemolytica var. ureae from sputa and stated that it occured in almost $1 \%$ of all their sputum specimens. In the same period, these investigators isolated $P$. multocida on two occasions only.

Whether or not the organism described in this communication should be given a name is open to question. If a name seems worthy, then it is suggested that the tentative name of Pasteurella pseudotuberculosis var. haemolytica be ascribed to it by reason of its similarities to $P$. pseudotuberculosis in that it is motile at $22^{\circ} \mathrm{C}$. and grows on bile salt agar, and its dissimilarity in exhibiting beta haemolysis.

\section{CONCLUSIONS}

The strain of Pasteurella discussed differs from the species at present known. This was established after comparison with $P$. pseudotuberculosis, $P$. pneumotropica, and the recently identified species $P$. haemolytica var. ureae, and it is suggested, in the light of other publications, that there is now sufficient evidence to indict species other than $P$. pestis as being human pathogens of some importance.

Because of its similarities to $P$. pseudotuberculosis, it is tentatively suggested that this organism be called Pasteurella pseudotuberculosis var. haemolytica.

The authors wish to thank Dr. Henriksen, Kaptein W. Wilhelmsen og Frues Bakteriologiske Institutt, Oslo University, and Dr. Jones, Public Health Laboratory, Manchester, for willingly supplying the cultures used for the comparative studies. Thanks are also due to Professor A. Currie, Department of Pathology, University of Aberdeen, for sections of the patient's appendix.

\section{REFERENCES}

Allin, A. E. (1942). Canad. med. Ass. J., 46, 48.

Allott, E. N., Cruickshank, R., Cyrlas-Williams, R., Glass, V., Meyer, I. H., Straker, E. A., and Tee, G. (1944). J. Path. Bact., 56, 411. Bartley, E. O. (1960). Lancet, 2, 581.

- , and Hunter, K. (1947). Ibid, 1, 908.

Bezjak, V., and Mimica, M. (1952). Brit med. J., $2,757$.

Boèr, W. von. (1917). Zbl. Bakt., I. Abt. Orig., 79, 390.

Boisvert, P. L., and Fousek, M. D. (1941). J. Amer. med. Ass., 116, 1902.

Brodie, J., and Henderson, A. (1960). Scot. med. J., 5, 452.

- (1963). Ibid., in press.

Brugnatelli, E. (1913). Zbl. Bakt., I. Abt. Orig., 70, 337.

Brundson, D. F. V., and Mallett, B. L. (1953). Brit. med. J., 2, 607.

Cawson, R. A., and Talbot, J. M. (1955). J. clin. Path., 8, 49.

Coghlan, J. D. (1958). J. Path. Bact., 76, 45.

Cooper, T. V., and Moore, B. (1945). Lancet, 1, 753.

Daniëls, J. J. H. M. (1961). Brit. med. J., 2, 997.

Debré, R. (1919). C. R. Soc. Biol. (Paris), 82, 224.

Emson, H. E. (1957). J. clin. Path., 10, 187.

Foerster, W. (1938). Klin. Wschr., 17, 599.

Henriksen, S. D. (1961). Acta path. microbiol. scand., 53, 425.

$\longrightarrow$, and Jyssum, K. (1960). Ibid., 50, 443.

- (1961). Ibid., 51, 354.

Hundeshagen, K. (1919). Med. Klin., 15, 1008.

Jones, D. M. (1962). J. Path. Bact., 83, 143.

-, and O'Connor, P. M. (1962). J. clin. Path., 15, 247.

Knapp, W. (1954). Zbl. Bakt., I. Abt. Orig., 161, 422.

- and Masshoff, W. (1954). Dtsch. med. Wschr., 79, 1266.

Lataix, P., Mollaret, H., Coulet, M., and Perny, M. (1959). Mém. Acad. Chir., 85, 721 .

Lee, M. L. H., and Buhr, A. J. (1960). Brit. med. J., 1, 169.

Ludlam, G. B. (1944). J. Path. Bact., 56, 307.

McGeachie, J. (1958). Ibid., 75, 467.

Mair, N. S., Mair, H. J., Stirk, E. M., and Corson, J. G. (1960). J. clin. Path., 13, 432.

Mautner, L. S., and McIntyre, J. A. (1956). Canad. med. Ass. J., 75, 218.

Mollaret, H. H. (1960). Presse méd., 68, 1447.

Mulder, J. (1938). Acta med. scand., 97, 165.

Omland, T., and Henriksen, S. D. (1961). Acta path. microbiol. scand., $53,117$.

Ortscheit, E. (1921). C. R. Soc. Biol. (Paris)., 84, 941.

Pizey, N. C. D. (1953). Lancet, 2, 324.

Randall, K. J., and Mair, N. S. (1962). Ibid., 1, 1042.

Regamey, R. (1938). Schweiz. med. Wschr., 68, 666.

Robinson, R. (1944). Brit. med. J., 2, 725.

Teissier, P., Gastinel, P., Reilly, J., and Rivallier (1922). J. Physiol. Path. gén., 20, 241.

Williams, E. (1960). Brit. med. J., 2, 1926. 